\title{
Anthropogenic Pressure and Lifestyle are the Underlying Cause of Pandemic Chronic Diseases
}

\author{
Dimitris Tsoukalas ${ }^{\mathrm{a}, \mathrm{b}, \mathrm{c}}$, Evangelia Sarandi ${ }^{\mathrm{a}, \mathrm{b}}$, \\ Aristides Tsatsakis*b,d and Daniela Calina ${ }^{c}$ \\ ${ }^{a}$ Metabolomic Medicine Clinic, Health Clinics \\ for Autoimmune and Chronic Diseases \\ 5 Koubari, Kolonaki, Athens, 10674, Greece \\ ${ }^{b}$ University of Crete, Medical School, Laboratory of Toxicology \\ Voutes, Heraklion, 71003, Greece \\ 'University of Medicine and Pharmacy, Faculty of Pharmacy \\ 2 Strada Petru Rareș, Craiova, 200349, Romania \\ ${ }^{d}$ Toxplus Spin-Off S.A. \\ 1 Agiou Fanouriou, Nea Alikarnassos, Heraklion, 71601, Greece
}

Dramatic changes in the environment in recent decades have resulted in low-nutrient food and excessive intake of heavy metals and toxins through air, drinking water, and dietary habits. Noncommunicable diseases (NCD), which are responsible for almost $70 \%$ of global deaths, are mainly caused by modifiable risk factors. These include behavioral and metabolic risk factors such as unhealthy diet, tobacco smoke and alcohol. Epigenetic factors have high attributable risks of 80\% for most NCDs. Xenobiotics such as persistent organic pollutants, food additives and occupational toxicants, together with nutritional deficiencies, contribute to the development of chronic diseases. Precision medicine integrates the individual variability in genes, environment, and lifestyle of each person for the prevention and treatment of disease. Metabolomics, the quantitative and comprehensive evaluation of metabolites, has emerged as a novel and powerful tool in precision medicine. Analysis of metabolites gives precise data on nutritional deficiencies, metabolic imbalances, environmental toxins, and microbiome conditions and uncovers underlying genetic predispositions that can be modified through diet, lifestyle, supplements or medic ations. Critical signs of systemic dysfunction at the molecular level can be revealed years before clinical symptoms appear. Thus, through the assessment of the overall health status, early detection of diseases and intervention to restore these deficiencies is feasible. Lifestyle interventions to improve longevity and metabolic balance are being discussed.

(C) Siberian Federal University. All rights reserved

This work is licensed under a Creative Commons Attribution-NonCommercial 4.0 International License (CC BY-NC 4.0).

* Corresponding author E-mail address: aris@med.uoc.gr

ORCID: 0000-0001-6885-6209 (Tsoukalas D.); 0000-0003-3824-2462 (Tsatsakis A.) 
Keywords: metabolomics, diet, xenobiotics, chronic disease.

Citation: Tsoukalas D., Sarandi E., Tsatsakis A., Calina D. Anthropogenic pressure and lifestyle are the underlying cause of pandemic chronic diseases. J. Sib. Fed. Univ. Biol., 2019, 12(3), 233-243. DOI: 10.17516/1997-1389-0297.

\title{
Антропогенное давление и образ жизни - основная причина пандемических хронических заболеваний
}

\author{
Д. Тсоукалас ${ }^{\mathrm{a}, \tilde{,}, \mathrm{b}}$, Е. Саранди ${ }^{\mathrm{a}, \tilde{0}}$, \\ А. Тсатсакис ${ }^{б, г}$, Д. Калина ${ }^{\mathrm{B}}$ \\ ${ }^{a}$ Клиника метаболомной медицины, Клиники здоровья \\ при аутоиммунных и хронических заболеваниях \\ Греичия, 10674, Афинь, Колонаки, Кубари, 5 \\ бЛаборатория токсикологии \\ Медицинский институт, Университет Крита \\ Греция, 71003, Ираклион, Вуте \\ ${ }^{8}$ Фармацевтический факультет \\ Университет медицины и фармации \\ Румыния, 200349, Крайова, Страда Петру Рареш, 2 \\ `Акиионерное общество "Toxplus Spin-Off» \\ Греция, 71601, Ираклион, Неа Аликарнассос, Агиу Фанориу, 1
}

Резкие изменения окружающей среды в последние десятилетия привели к недостатку питательных веществ в пище $u$ чрезмерному потреблению тяжельх металлов $u$ токсинов через воздух, питьевую воду, за счет пищевых привычек. Неинфекичионные заболевания (НИЗ), которые являются причиной почти 70 \% смертей в мире, в основном вызваны модифицируемыми факторами риска. $K$ ним относятся поведенческие и метаболические факторы риска, такие как неправильное питание, курение табака и алкоголь. Эпигенетическим факторам приписывают 80 \% рисков для большинства НИЗ. Ксенобиотики, такие как стойкие органические загрязнители, пищевые добавки и производственные токсиканты, наряду с дефицитом питательных веществ, способствуют развитию хронических заболеваний. Точная медицина объединяет индивидуальную изменчивость в генах, особенности окружающей среды и образа жизни каждого человека для профилактики и лечения заболеваний. Метаболомика, количественная и всесторонняя оценка метаболитов, стала новым и мощңным инструментом в точной медицине. Анализ метаболитов дает точные данные о дефиците питательных веществ, метаболическом дисбалансе, токсинах окружающей среды, состоянии микробиома и раскрывает основные генетические предрасположенности, которые можно изменить с помощью диеты, образа жизни, добавок или лекарств. Критические признаки системной дисфункиии 
на молекулярном уровне могут быть выявлены за годы до возникновения клинических симптомов. Таким образом, посредством оценки общего состояния здоровья возможно раннее выявление заболеваний и вмешательство для устранения этих недостатков. В статье обсуждаются мероприятия по улучшению образа жизни для увеличения долголетия и улучшения метаболического баланса.

Ключевые слова: метаболомика, диета, ксенобиотики, хронические заболевания.

\section{Introduction}

Humans have developed mechanisms to combat continuous exposure to harmful agents, which have multiplied during evolution and economic industrialization (Golokhvast et al., 2015; Veskoukis et al., 2012). However, rapid cultural changes have overcome the possibility of genetic adaptation, leading to an increase in chronic diseases (Eaton et al., 1988). It has been suggested that chronic diseases are the human body's attempt to adapt to harmful lifestyle behaviors (Ruiznúñez et al., 2013). According to the World Health Organization (Fig. 1), 80\% of diseases, such as cancer, heart disease, and autoimmune diseases, are due to lifestyle and diet (WHO, 2019).

\section{The role of toxicants}

Living in a highly toxic environment including occupational, environmental, biotoxic, and lifestyle concomitant factors, has significantly burdened defense mechanisms (Gangemi et al., 2016). The toxic burden is aggravated by constant exposure to pesticides, heavy metals, food additives, and endocrine disruptors (Docea et al., 2018; Hernandez and Tsatsakis, 2017; Tsatsakis et al., 2016).

Environmental pollutants such as dioxins, which are in the group of persistent organic pollutants, are considered highly dangerous to health (Iatrou et al., 2019; Vassilopoulou et al., 2017). Dioxins are toxic to many organs and have long half-lives ( 7 to 11 years), and humans, who are at the top of the food

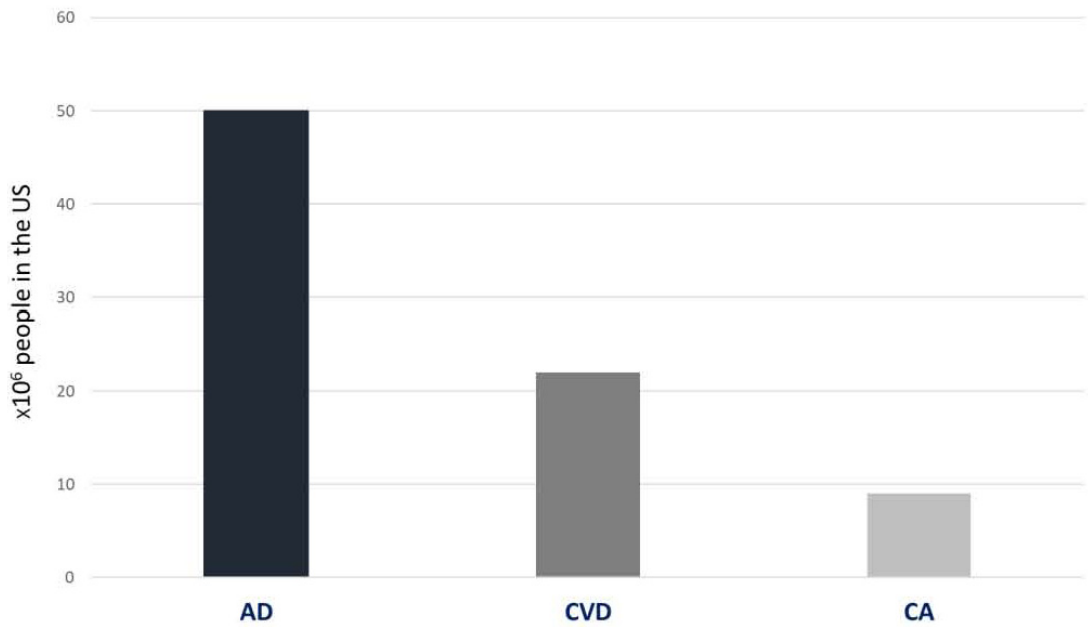

Fig. 1. Morbidity rates for chronic diseases. Autoimmune diseases (ADs), cardiovascular disease (CVD), cancer (CA) (American Autoimmune-Related Diseases Association) 
chain, receive high concentrations of dioxins (WHO, 2016; Iatrou et al., 2019). For example, 2,3,7,8-tetrachlorodibenzo-para-dioxin (TCDD) has been classified as a "known human carcinogen" by the WHO's International Agency for Research on Cancer (IARC). In addition, several studies have associated levels of polychlorinated biphenyls (PCBs) and dichl orodiphenyldichloroethylene (DDE) in adipose tissue with cancer (Xu et al., 2016). Apart from cancer, dioxins have also been linked to cardiovascular disease, mood changes and cognitive function even 10 years after the initial exposure (Kodavanti, 2005). PCB exposure resulted in high levels of HDL-cholesterol and triglycerides in the blood, even in the absence of signs of intoxication (Lee et al., 2011). Other related conditions include thyroid disease, diabetes, stress, and fatigue (Gaum et al., 2019). Di-(2-ethylheyl) phthalate (DEHP), a compound used in plastic, didecyldimethylammonium chloride (DDAC) and ethylene glycol (EG) have been shown to trigger inflammatory responses in animal models (Guo et al., 2012; Kwon et al., 2016). DNA methylation, the on and off switch mechanism of genes, is an additional mechanism in which environmental pollutants, smoking, and alcohol consumption have been shown to affect the inflammatory response (Baccarelli et al., 2009; Bigazzi, 1997).

In a systematic review of 103 articles on autoimmunity and chemical exposures, the authors concluded that multiple sclerosis, systemic sclerosis and primary systemic vasculitis were associated with organic solvents and that people carrying autoimmunity genetic variants need to avoid organic solvents (Barragan-Martinez et al., 2012). Reactive organic compounds cause toxicant-induced immunity through multiple mechanisms, and two of the most common are as follows: 1 . They cause sudden cellular apoptosis, which exposes cell material to the antigen presenting cells; and 2. They bind to human tissue, covalently forming neoantigens, thus inducing an inflammatory response. For example, halogenated compounds found in nail polish have been reported to bind to mitochondrial proteins, inducing antimicrobial antibodies and primary biliary cirrhosis (PBC) (Vojdani, 2014).

Modern living is characterized by intense stress, lack of water and consumption of processed foods that have lost their nutritional value and are high in calories, chemical additives, sugar, and fats, which deteriorate health (Bosma-den Boer et al., 2012; Vakonaki et al., 2017). Monosodium glutamate (MSG), a food enhancer widely used in Chinese food and found in many processed foods, has been linked to several chronic diseases, especially after long periods of consumption (Zanfirescu et al., 2019). Salt has been directly linked to hypertension and cardiovascular mortality (Karppanen and Mervaala, 2006). In a salt-reduction program, which started during the 1970s and was supported by industries and government, the Finnish tried to reduce salt intake and achieved a $75 \%$ mortality reduction and a lifespan extension of 6-7 years. Unprocessed sea salt, which contains over 80 essential minerals and elements, is indispensable for the normal function of the thyroid, adrenal glands and the nervous system, and for natural detoxification. Industrially processed food items have significantly altered ratios of sodium, potassium, calcium, and magnesium, which exert the hypertensive effect of salt. A determinant factor of the success of the salt reduction program in Finland was the consumption of sodium-reduced, potassium-and magnesium-enriched healthier salt alternatives, highlighting the pivotal role of nutrient intake at the correct ratios (Karpanen et al., 1984; Geleijnse et al., 1994). 


\section{Diet and dietary patterns associated with chronic diseases}

What would be an ideal and healthy diet? The Mediterranean diet, the vegetarian diet, the "paleo" diet, fasting, intermittent fasting, the low glycemic index diet, the protein diet and the diet high in "good" fat and low in carbohydrates all are diets that have been successful for some people. However, this one-size-fits-all diet model has not been successful in combating chronic diseases, stressing the need for more precision medicine approaches (Clish, 2015; Zeisel et al., 2008).

A generally accepted concept is that eating fruits and vegetables is a healthy eating habit. However, studies have shown that before changing their traditional diet in the 1960s, Eskimos followed a diet consisting mainly of foods of animal origin - reindeer, seals, fish, whale fat without fruits and vegetables, and they had a low risk of heart disease (Dyerberg et al., 1975; Dinicolantonio and Keefe, 2018; Fumagalli et al., 2015).

The same was observed in populations living in the remote areas of central Africa where access to plant origin foods was practically impossible. The members of the Maasai tribe consumed meats and animal origin foods that contained enormous amounts of cholesterol, yet they did not develop atherosclerosis, coronary artery disease, diabetes, cancer or skin acne (Mann et al., 1964; Wagh et al., 2012; Biss et al., 1971).

In contrast, Asian populations, such as the Japanese, have excellent health and longevity by consuming traditional diets of mainly plant origin foods with a small amount of animal foods, usually fish or eggs (Seah et al., 2018). Meanwhile, Mediterranean populations, who follow a mixed diet, consuming both plant and animal origin foods such as meats, fish, eggs, olive oil, olives, sheep and goat dairy products, fruits, greens, legumes, nuts, salads and rutabaga nuts, also have excellent results in longevity and health (Papamichael et al., 2019a; Sacks et al., 2017; Faggi et al., 2019; Engin et al., 2018; Tsoukalas et al., 2019). Therefore, one would not expect to give rice to Eskimos or feta cheese to Asians and have positive health effects (Dyerberg et al., 1975; Dinicolantonio and Keefe, 2018; Fumagalli et al., 2015; Wagh et al., 2012; Biss et al., 1971; Mann et al., 1964). However, such an effect does not mean that rice or feta are unhealthy foods.

In recent years, for example, atopic dermatitis has been a common childhood disease, affecting $26.5 \%$ of children aged $12-23$ months in Korea (Yu et al., 2012). These children consume, among other things, rice 4-5 times per day, as rice is a primary food in Korea and accompanies all meals. Preliminary results from the metabolomic analysis performed in these children showed that reducing rice consumption to 2 times a day not only did not worsen their health but also improved atopic dermatitis progression (Tsoukalas, 2018a). However, if we recommended that an American or a Mediterranean resident eat rice twice a day, we would considerably increase their risk of developing diabetes and obesity (Sun et al., 2010).

The above picture is further complicated considering that age, sex, and levels of physical activity and stress shape different nutritional needs and deficiencies.

\section{Metabolomics:}

\section{the science behind the phenotype}

Metabolomics can identify with precision what foods are best metabolized by an individual at a given time and what deficiencies or nutritional needs he/she has (Fig. 2) (Tsoukalas et al., 2017; Tsoukalas et al., 2019; Zeisel et al., 2008). Metabolomics is the science that measures the small molecules that shape human metabolism. Metabolism refers to all the chemical reactions that keep us alive and includes the absorption 


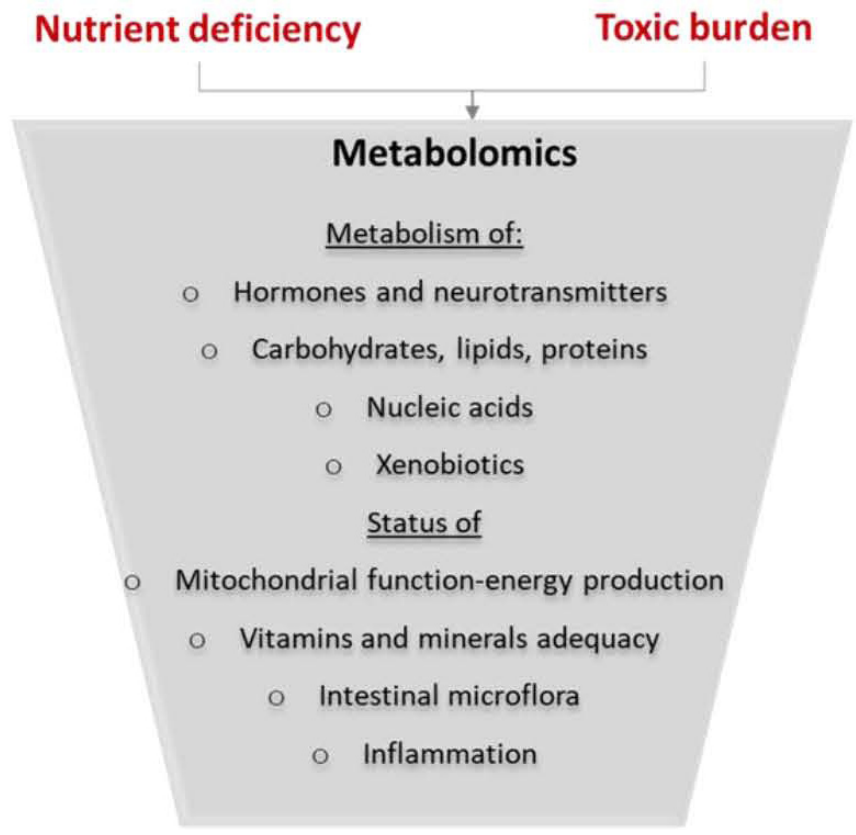

Fig. 2. Metabolomics can A. assess the metabolism of hormones, carbohydrates, lipids, proteins, nucleic acids, and xenobiotics. B. provide information on the status of mitochondrial function, vitamin and mineral levels, intestinal microflora and inflammation

of food, the production of energy, and the construction of cells that form the skin, the muscles, and the organs, as well as substances such as hormones, that regulate body functions (Guijas et al., 2018).

All possible combinations of lifestyle, nutrition, body deficiencies, and pharmaceutical interventions are potentially infinite. Metabolomics measures what is happening within the body and indicates the exact combination of interventions that will bring the best therapeutic effect if we can substantially intervene and improve health (Trivedi et al., 2017; Papamichael et al., 2019). Additionally, it provides accurate data for the treatment and prevention of chronic and autoimmune inflammatory diseases such as diabetes, hypertension, thyroid disease, lupus erythematosus, rheumatoid arthritis, psoriasis, Hashimoto's, Crohn's disease, atopic dermatitis, allergies, asthma, and others (Kang et al., 2015; Huang et al., 2014; Sirotti et al., 2017; Papamichael et al., 2019).

\section{Response to xenobiotics and drugs}

Drug treatment can have positive results in a percentage of the population, neutral to some and negative to others (Kantae et al., 2017). Metabolomics can assess the ability of the individual to metabolize a drug. Thus, it provides information that leads to the adaptation of treatment according to the patient's needs, aiming for the best response and the minimum adverse effects (Golomb and Evans, 2008; Mesnage et al., 2018). For example, the use of medication that reduces cholesterol levels has an absolute indication in people who have had a heart attack. Often, however, this class of drugs causes muscle aches, fatigue, increased blood sugar levels and depression (Golomb and Evans, 2008).

The above side effects arise mainly because they block the production of a major substance of the coenzyme Q10 (Kantae et al., 2017; Golomb and Evans, 2008). Some patients are more sensitive to this compound and some 
are less affected. Metabolomics can provide information on the effect of the drug on the patient, allowing the physician to modify the treatment and improve the patient's response and health progress.

\section{Towards health and longevity}

Health is not merely the absence of disease, but it requires the proper function of all the cells and systems to their full potential (Jadad and O'Grady, 2008). Metabolic imbalance and aging are common denominators in agingrelated diseases (Tsoukalas et al., 2018; Ames, 2006; Epel et al., 2004). Metabolomic Medicine Health Clinic and Toxplus, a University of Crete spinoff company, investigate the impacts of lifestyle on chronic diseases with the application of metabolomics (Tsoukalas et al., 2019; Tsoukalas et al., 2017; Papamichael et al., 2019) and highly advanced tools in telomere biology (Tsatsakis et al., 2019). Ongoing human studies indicate that nutritional supplementation is positively associated with longer telomeres (Tsoukalas et al., 2019a; Fragkiadaki et al., 2017) and improved neuroprotective mechanisms against ischemic episodes (Faggi et al., 2019). Individuals with asthma or atopic dermatitis have been shown to have altered metabolic pathways (Papamichael et al., 2019; Tsoukalas, 2018a), and ongoing clinical studies will define the metabolic fingerprints of rheumatoid arthritis, Hashimoto's thyroiditis, psoriasis, Crohn's disease, and ulcerative colitis to identify predictive biomarkers (Tsoukalas, 2018b).

\section{Acknowledgments}

This study is part of the special section of the $\mathrm{PhD}$ thesis from the University of Medicine and Pharmacy of Craiova. The authors would like to thank Metabolomic Medicine, Toxplus and the Laboratory of Toxicology administrative, medical and technical staff for their dedicated involvement in the study.

\section{References}

Ames B.N. (2006) Low micronutrient intake may accelerate the degenerative diseases of aging through allocation of scarce micronutrients by triage. Proceedings of the National Academy of Sciences of the United States of America, 103(47): 17589-17594

Baccarelli A., Wright R.O., Bollati V., Tarantini L., Litonjua A.A., Suh H.H., Zanobetti A., Sparrow D., Vokonas P.S., Schwartz J. (2009) Rapid DNA methylation changes after exposure to traffic particles. American Journal of Respiratory and Critical Care Medicine, 179(7): $572-578$

Barragan-Martinez C., Speck-Hernandez C.A., Montoya-Ortiz G., Mantilla R.D., Anaya J.M., Rojas-Villarraga A. (2012) Organic solvents as risk factor for autoimmune diseases: a systematic review and meta-analysis. PLoS ONE, 7(12): e51506

Bigazzi P.E. (1997) Autoimmunity caused by xenobiotics. Toxicology, 119(1): 1-21

Biss K., Ho K.-J., Mikkelson B., Lewis L., Taylor C.B. (1971) Some unique biologic characteristics of the Masai of East Africa. New England Journal of Medicine, 284(13): 694-699

Bosma-den Boer M.M., van Wetten M.L., Pruimboom L. (2012) Chronic inflammatory diseases are stimulated by current lifestyle: how diet, stress levels and medication prevent our body from recovering. Nutrition \& Metabolism, 9(1): 32

Clish C.B. (2015) Metabolomics: an emerging but powerful tool for precision medicine. Cold Spring Harbor Molecular Case Studies, 1(1): a000588 
DiNicolantonio J.J., O'Keefe J.H. (2018) The introduction of refined carbohydrates in the Alaskan inland Inuit diet may have led to an increase in dental caries, hypertension and atherosclerosis. Open Heart, 5(2): e000776

Docea A.O., Gofita E., Goumenou M., Calina D., Rogoveanu O., Varut M., Olaru C., Kerasioti E., Fountoucidou P., Taitzoglou I., Zlatian O., Rakitskii V.N., Hernandez A.F., Kouretas D., Tsatsakis A. (2018) Six months exposure to a real life mixture of 13 chemicals' below individual NOAELs induced non monotonic sex-dependent biochemical and redox status changes in rats. Food and Chemical Toxicology, 115: 470-481

Dyerberg J., Bang H.O., Hjorne N. (1975) Fatty acid composition of the plasma lipids in Greenland Eskimos. The American Journal of Clinical Nutrition, 28(9): 958-966

Eaton S.B., Konner M., Shostak M. (1988) Stone agers in the fast lane : chronic degenerative diseases in evolutionary perspective. The American Journal of Medicine, 84(4): 739-749

Engin A.B., Tsatsakis A.M., Tsoukalas D., Engin A. (2018) Do flavanols-rich natural products relieve obesity-related insulin resistance? Food and Chemical Toxicology, 112: 157-167

Epel E.S., Blackburn E.H., Lin J., Dhabhar F.S., Adler N.E., Morrow J.D., Cawthon R.M. (2004) Accelerated telomere shortening in response to life stress. Proceedings of the National Academy of Sciences of the United States of America, 101(49): 17312-17315

Faggi L., Porrini V., Lanzillotta A., Benarese M., Mota M., Tsoukalas D., Parrella E., Pizzi M. (2019) A polyphenol-enriched supplement exerts potent epigenetic-protective activity in a cell-based model of brain ischemia. Nutrients, 11(2): 345

Fragkiadaki P., Tsoukalas D., Alegakis A., Vlata C., Psycharakis C., Tsatsakis A. (2017) The effect of supplements on telomerase activation in human PBMC cells. Toxicology Letters, 280 (Supplement 1): $\mathrm{S} 319$

Fumagalli M., Moltke I., Graru N., Racimo F., Bjerregaard P., Jørgensen M.E., Korneliussen T.S., Gerbault P., Skotte L., Linneberg A., Christensen C., Brandslund I., Jørgensen T., Huerta-Sánchez E., Schmidt E.B., Pedersen O., Hansen T., Albrechtsen A., Nielsen R. (2015) Greenlandic Inuit show genetic signatures of diet and climate adaptation. Science, 349(6254): 1343-1347

Gangemi S., Gofita E., Costa C., Teodoro M., Briguglio G., Nikitovic D., Tzanakakis G., Tsatsakis A.M., Wilks M.F., Spandidos D.A., Fenga C. (2016) Occupational and environmental exposure to pesticides and cytokine pathways in chronic diseases (review). International Journal of Molecular Medicine, 38(4): 1012-1020

Gaum P.M., Gube M., Esser A., Schettgen T., Quinete N., Bertram J., Putschögl F.M., Kraus T., Lang J. (2019) Depressive symptoms after PCB exposure : hypotheses for underlying pathomechanisms via the thyroid and dopamine system. International Journal of Environmental Research and Public Health, 16(6): 950

Geleijnse J.M., Witteman J.C.M., Bak A.A.A., den Breijen J.H., Grobbee D.E. (1994) Reduction in blood pressure with a low sodium, high potassium, high magnesium salt in older subjects with mild to moderate hypertension. British Medical Journal, 309(6952): 436-440

Golokhvast K., Vitkina T., Gvozdenko T., Kolosov V., Yankova V., Kondratieva E., Gorkavaya A., Nazarenko A., Chaika V., Romanova T., Karabtsov A., Perelman J., Kiku P., Tsatsakis A. (2015) Impact of atmospheric microparticles on the development of oxidative stress in healthy city / industrial seaport residents. Oxidative Medicine and Cellular Longevity, 2015: ID 412173 
Golomb B.A., Evans M.A. (2008) Statin adverse effects: a review of the literature and evidence for a mitochondrial mechanism. American Journal of Cardiovascular Drugs, 8(6): 373-418

Guijas C., Montenegro-Burke J.R., Warth B., Spilker M.E., Siuzdak G. (2018) Metabolomics activity screening for identifying metabolites that modulate phenotype. Nature Biotechnology, 36(4): $316-320$

Guo J., Han B., Qin L., Li B., You H., Yang J., Liu D., Wei C., Nanberg E., Bornehag C.G., Yang X. (2012) Pulmonary toxicity and adjuvant effect of di-(2-exylhexyl) phthalate in ovalbuminimmunized BALB/c mice. PLoS ONE, 7(6): e39008

Hernandez A.F., Tsatsakis A.M. (2017) Human exposure to chemical mixtures: challenges for the integration of toxicology with epidemiology data in risk assessment. Food and Chemical Toxicology, 103: 188-193

Huang Y., Chen G., Liu X., Shao Y., Gao P., Xin C., CuiZ., Zhao X., Xu G. (2014) Serummetabolomics study and eicosanoid analysis of childhood atopic dermatitis based on liquid chromatography - mass spectrometry. Journal of Proteome Research, 13(12): 5715-5723

Iatrou E.I., Tsygankov V., Seryodkin I., Tzatzarakis M.N., Vakonaki E., Barbounis E., Zakharenko A.M., Chaika V.V., Sergievich A.A., Tsatsakis A.M., Golokhvast K. (2019) Monitoring of environmental persistent organic pollutants in hair samples collected from wild terrestrial mammals of Primorsky Krai, Russia. Environmental Science and Pollution Research, 26(8): 7640-7650

Jadad A.R., O’Grady L. (2008) How should health be defined? British Medical Journal, 337 : a2900

Kang J., Zhu L., Lu J., Zhang X. (2015) Application of metabolomics in autoimmune diseases: insight into biomarkers and pathology. Journal of Neuroimmunology, 279: 25-32

Kantae V., Krekels E.H.J., Van Esdonk M.J., Lindenburg P., Harms A.C., Knibbe C.A.J., Van Der Graaf P.H., Hankemeier T. (2017) Integration of pharmacometabolomics with pharmacokinetics and pharmacodynamics: towards personalized drug therapy. Metabolomics, 13(1): 9

Karppanen H., Tanskanen A., Tuomilehto J., Puska P., Vuori J., Jantti V., Seppanen M.-L. (1984) Safety and effects of potassium- and magnesium- containing low sodium salt mixtures. Journal of Cardiovascular Pharmacology, 6 (Supplement 1): S236-S243

Karppanen H., Mervaala E. (2006) Sodium intake and hypertension. Progress in Cardiovascular Diseases, 49(2): 59-75

Kodavanti P.R.S. (2005) Neurotoxicity of persistent organic pollutants: possible mode(s) of action and further considerations. Dose-Response, 3(3): 273-305

Kwon D.Y., Kim H.M., Kim E., Lim Y.M., Kim P., Choi K., Kwon J.T. (2016) Acute pulmonary toxicity and inflammation induced by combined exposure to didecyldimethylammonium chloride and ethylene glycol in rats. The Journal of Toxicological Sciences, 41(1): 17-24

Lee D.H., Steffes M.W., Sjoedin A., Jones R.S., Needham L.L., Jacobs D.R.Jr. (2011) Low dose organochlorine pesticides and polychlorinated biphenyls predict obesity, dyslipidemia, and insulin resistance among people free of diabetes. PLOS ONE, 6(1): e15977

Mann G.V., Shaffer R.D., Anderson R.S., Sandstead H.H., Prendergast H., Mann J.C., Rose S., Powell-Jackson J., Moitanik S., Ol Monah J., Isaac S.M., Msangi O.H., Frank E., Martin J., Lane J., Rasmussen I., Dicks K. (1964) Cardiovascular disease in the masai. Journal of Atherosclerosis Research, 4(4): 289-312 
Mesnage R., Antoniou M.N., Tsoukalas D., Goulielmos G.N., Tsatsakis A.M. (2018) Gut microbiome metagenomics to understand how xenobiotics impact human health. Current Opinion in Toxicology, 11-12: 51-58

Papamichael M.M., Katsardis C., Erbas B., Itsiopoulos C., Tsoukalas D. (2019) Urinary organic acids as biomarkers in the assessment of pulmonary function in children with asthma. Nutrition Research, 61: 31-40

Papamichael M.M., Katsardis C., Lambert K., Tsoukalas D., Koutsilieris M., Erbas B., Itsiopoulos C. (2019a) Efficacy of a mediterranean diet supplemented with fatty fish in ameliorating inflammation in paediatric asthma: a randomised controlled trial. Journal of Human Nutrition and Dietetics, 32(2): 185-197

Ruiz-núñez B., Pruimboom L., Dijck-Brouwer D.A.J., Muskiet F.A.J. (2013) Lifestyle and nutritional imbalances associated with western diseases: causes and consequences of chronic systemic low-grade inflammation in an evolutionary context. Journal of Nutritional Biochemistry, 24(7): 1183-1201

Sacks F.M., Lichtenstein A.H., Wu J.H.Y., Appel L.J., Creager M.A., Kris-Etherton P.M., Miller M., Rimm E.B., Rudel L.L., Robinson J.G., Stone N.J., Van Horn L.V. (2017) Dietary fats and cardiovascular disease: a presidential advisory from the American heart association. Circulation, 136(3): el-e23

Seah J.Y.H., Koh W.P., Yuan J.M., Van Dam R.M. (2018) Rice intake and risk of type 2 diabetes: the Singapore Chinese Health Study. European Journal of Nutrition

Sirotti S., Generali E., Ceribelli A., Isailovic N., De Santis M., Selmi C. (2017) Personalized medicine in rheumatology: the paradigm of serum autoantibodies. Autoimmunity Highlights, 8(1): UNSP 10

Sun Q., Spiegelman D., Van Dam R.M., Holmes M.D., Malik V.S., Willett W.C., Hu F.B. (2010) White rice, brown rice, and risk of type 2 diabetes in US men and women. Archives of Internal Medicine, 170(11): 961-969

Trivedi D.K., Hollywood K.A., Goodacre R. (2017) Metabolomics for the masses: the future of metabolomics in a personalized world. New Horizons in Translational Medicine, 3(6): 294-305

Tsatsakis A.M., Docea A.O., Tsitsimpikou C. (2016) New challenges in risk assessment of chemicals when simulating real exposure scenarios; simultaneous multi-chemicals' low dose exposure. Food and Chemical Toxicology, 96: 174-176

Tsatsakis A., Tsoukalas D., Fragkiadaki P., Vakonaki E., Tzatzarakis M., Sarandi E., Nikitovic D., Tsilimidos G., Alegakis A.K. (2019) Developing BIOTEL: a semi-automated spreadsheet for estimating telomere length and biological age. Frontiers in Genetics, 10: 84

Tsoukalas D. (2018a) Advances in clinical application of metabolomics: treating children with atopic dermatitis. Dermatology and the Borderline Specialties, Primaderma 23-27 May

Tsoukalas D. (2018b) World aging population, chronic diseases and impact of modifiable-metabolic risk factors. 20th Congress of the International Association of Rural Health and Medicine (IARM20), p. 52

Tsoukalas D., Alegakis A., Fragkiadaki P., Papakonstantinou E., Nikitovic D., Karataraki A., Nosyrev A.E., Papadakis E.G., Spandidos D.A., Drakoulis N., Tsatsakis A.M. (2017) Application of metabolomics: focus on the quantification of organic acids in healthy adults. International Journal of Molecular Medicine, 40(1): 112-120 
Tsoukalas D., Alegakis A.K., Fragkiadaki P., Papakonstantinou E., Tsilimidos G., Geraci F., Sarandi E., Nikitovic D., Spandidos D.A., Tsatsakis A. (2019) Application of metabolomics part II: focus on fatty acids and their metabolites in healthy adults. International Journal of Molecular Medicine, 43(1): 233-242

Tsoukalas D., Fragkiadaki P., Docea A.O., Alegakis A.K., Sarandi E., Vakonaki E., Salataj E., Kouvidi E., Nikitovic D., Kovatsi L., Spandidos D.A., Tsatsakis A., Calina D. (2019a) Association of nutraceutical supplements with longer telomere length. International Journal of Molecular Medicine, 44(1): 218-226

Tsoukalas D., Fragkiadaki P., Sarandi E., Tsatsakis A. (2018) Modulation of the process of aging in human organism: recent advances in biomarkers for diagnosis and treatment. Journal of Siberian Federal University. Biology, 11(2): 146-156

Vakonaki E., Fragkiadaki P., Tsoukalas D., Alegkakis A., Vaki G., Tsiminikaki K., Plaitis S., Tzatzarakis M., Tsatsakis A. (2017) Telomere length in opiates and cannabis abusers as a marker of early aging. Toxicology Letters, 280: S242

Vassilopoulou L., Psycharakis C., Petrakis D., Tsiaoussis J., Tsatsakis A.M. (2017) Obesity, persistent organic pollutants and related health problems. Obesity and Lipotoxicity. Advances in Experimental Medicine and Biology, vol 960. Engin A., Engin A. (eds.) Springer, Cham, p. 81-110

Veskoukis A.S., Tsatsakis A.M., Kouretas D. (2012) Dietary oxidative stress and antioxidant defense with an emphasis on plant extract administration. Cell Stress and Chaperones, 17(1): 11-21

Vojdani A. (2014) A potential link between environmental triggers and autoimmunity. Autoimmune Diseases, 2014: ID 437231

Wagh K., Bhatia A., Alexe G., Reddy A., Ravikumar V., Seiler M., Boemo M., Yao M., Cronk L., Naqvi A., Ganesan S., Levine A.J., Bhanot G. (2012) Lactase persistence and lipid pathway selection in the Maasai. PLoS ONE, 7(9): e44751

WHO (2016) Dioxins and their effects on human health. https://www.who.int/news-room/factsheets/detail/dioxins-and-their-effects-on-human-health

WHO (2019) Global health observatory (GHO) data global health. Observatory data noncommunicable diseases (NCD). https://www.who.int/gho/ncd/en/

Xu J., Ye Y., Huang F., Chen H., Wu H., Huang J., Hu J., Xia D., Wu Y. (2016) Association between dioxin and cancer incidence and mortality: a meta-analysis. Scientific Reports, 6: 38012

Yu J.S., Lee C.J., Lee H.S., Kim J., Han Y., Ahn K., Lee S.I. (2012) Prevalence of atopic dermatitis in Korea: analysis by using national statistics. Journal of Korean Medical Science, 27(6): 681-685

Zanfirescu A., Ungurianu A., Tsatsakis A.M., Nițulescu G.M., Kouretas D., Veskoukis A., Tsoukalas D., Engin A.B., Aschner M., Margină M. (2019) A review of the alleged health hazards of monosodium glutamate. Comprehensive Reviews in Food Science and Food Safety, 18(4): 1111-1134

Zeisel S.H., Freake H.C., Bauman D.E., Bier D.M., Burrin D.G., German J.B., Klein S., Marquis G.S., Milner J.A., Pelto G.H., Rasmussen K.M. (2008) The nutritional phenotype in the age of metabolomics. Journal of Nutrition, 135(7): 1613-1616 